International Research Journal of Management, IT \& Social Sciences
Available online at https://sloap.org/journals/index.php/irjmis/
Vol. 7 No. 1, January 2020, pages: 242-257
ISSN: 2395-7492
https://doi.org/10.21744/irjmis.v7n1.843

\title{
Teaching Writing Skills through Genre: Applying the Genre-based Approach in Iran
}

Somayye Ariyanfar ${ }^{\mathrm{a}}$ Rod Mitchell ${ }^{b}$

\section{Article history:}

Submitted: 09 November 2019

Revised: 27 December 2019

Accepted: 18 January 2020

Keywords:

academic writing;

argumentative rhetoric;

consciousness-Raising

approach;

EFL students;

genre-based pedagogy;

\begin{abstract}
Developing effective argumentative and persuasive texts is a challenge for both native and non-native students of writing skills, where a lack of linguistic, rhetorical, and cultural awareness skills are major problems in effective written communication. International research results show that a Genre-Based Approach based in particular on Systemic Functional and Cognitive Linguistics allows students to take a significant leap towards controlling macro and micro-genre structures as well as language and that taking a consciousnessraising approach to genre seems to be a key contributing factor to better writing development. We report on the findings of two recent Iranian studies, one that implemented the Genre-Based Approach, and the other Mobile-Assisted Dynamic Assessment following mixed Product-Process methodology, as well as giving an overview of some recent research into the development of academic writing skills through genre teaching-learning in contrast to traditional approaches. Results show that, though traditional methodologies can have success, the Genre-Based Approach, with its focus on better genre characteristics identification along with improved teaching and learning methodology, combining elements of structure, language, rhetoric, and cultural contextualization, gives more rapid results, and leads to better and more confident writers, as well as better syllabus development.
\end{abstract}

International research journal of management, IT and social sciences (C) 2020. This is an open access article under the CC BY-NC-ND license (https://creativecommons.org/licenses/by-nc-nd/4.0/).

Corresponding author:

Somayye Ariyanfar,

Safir Language Academy, Fars, Iran.

Email address: pan.22.ariyanfar@gmail.com

Safir Language Academy, Fars, Iran

Linguarama Milan, Milan, Italy 


\section{Introduction}

Writing is often felt by language students to be the most difficult skill among the four major skills of Speaking, Listening, Reading, and Writing. Teachers can also have a hard time imparting strong writing skills. Using researchbased on Systemic Functional (SFL) and teaching-learning processes based on Cognitive Linguistics (CL) pioneered in Australia and elsewhere, we look at means of teaching, learning, and self-teaching writing skills through the GenreBased Approach. We particular reference to a case study which formed the research component for a Master's thesis (Jodairi Pineh \& Ariyanfar, 2018), based on eight months of coursework where the principles of the Genre Approach were applied so as to assess their potentiality for the Iranian context. These were contrasted with a selection of IELTS writing tasks produced as part of an Iranian study (Nasiri \& Moeinpour, 2018) into the dynamic assessment of IELTS Writing Task 1, taught through the more traditional product-process methodology. The Genre-Based Approach is a guide to helping learners develop their writing skills through making them aware of the important role that contextualization plays while writing, as well as helping teachers identify the structural, linguistic, and social characteristics of the different types of texts that learners will need to produce in the target language, and therefore how to make the teaching and learning of these more effective.

\section{Materials and Methods}

\section{Learning to Write}

Learning to write in one's first language is a long, drawn-out affair, starting from the moment we start school and then continuing on through all levels of education well into adulthood. It is a cultural, communicative, and rhetorical process, based on the speech and sociolinguistic patterns of our language, and involves developing proficiency in a range of communicative acts: stylistics, rhetorical devices, grammar awareness, contextual awareness (setting, audience, and readership), the physical aspects of writing, research, and thought processes. In short, a range of both complex and simple input that goes into creating written communication.

It is problematic for both native and non-native students to develop sound argumentative genres, as early studies in argumentative and persuasive genres in native and EFL contexts revealed, such as Andrews (2005); Connor et al. (1987); Crowhurst (1988), Davis \& McKay (1996); Johns (1993); Knudson (1994); and Stuart-Smith (1998). Studies carried out by Arsyad (1999); Choi (1988); Hounhanou (2018); Connor \& Tuija (1988); Hirose (2003); Johns (1993); Mohan \& Lo (1985); and Thompson (2001), found that undergraduate students from East Asian countries experience severe problems in producing argumentative texts, with a lack of linguistic and rhetorical skills in the target language being reported as the main problems in producing a sound persuasive text.

In addition, the non-native has already learned various aspects of writing and rhetoric in his or her first language or at least is well into the process of doing so. It is common for EFL learners to transfer aspects of not only their language but also their writing traditions. Hamzaoui Elachachi (2015), explored this in her paper on "Exploring cultural barriers in EFL Arab learners' writing", where she demonstrated that "because Arab writers bring with them their cultural experiences that affect their writing, EFL teaching may not be successful if the underlying culture in L1 is not addressed, or if contrasts between L1 and FL writing structures are not made sufficiently explicit" (p. 135).

Seeing that communication exists within socio-cultural settings, the non-native writer needs to learn how to handle the expectations of communication within the world of the new language. All too often the focus in EFL writing classes on language (grammar, wording, syntax) and text structure of genre is based on principles of Structuralism and Functionalism as well as being teacher-led. Systemic Functional, Communicative, Task-Based Learning (TBL), and Cognitive Approaches in contrast place more focus on the student, on student-student, and on student-teacher teamwork in learning to write more effectively; there is more emphasis on the practical give-and-take of learning to handle writing in another language, in particular by back grounding cultural, social, and theoretical awareness. Designing coursework and educational materials combining insights from applied CL and SFL theory with corpusbased and authentic materials learning to appear to maximize learner exposure to naturally occurring meaning and usage in language, and to enhance the effectiveness of potential acquisition (cf. Dolgova \& Tyler, 2019).

Ariyanfar, S., \& Mitchell, R. (2020). Teaching writing skills through genre: Applying the genre-based approach in Iran. International Research Journal of Management, IT and Social Sciences, 7(1), 242-257. 
Approaches to Teaching Writing

The most common approaches to teaching writing fall into three types:

a) Product-Based Approach, a totally "teacher-centered, examination-oriented teaching culture" (Pennington, 1995);

b) Process Approach viewed as being "interpretational, learner-centered and not specifically related to examinations" (Pennington, 1995);

c) Genre-Based Approach, a mix of Process and Product Approaches which emerged as a response to the Process Approach formerly prominent in the US (Horowitz, 1986).

The Product Approach emphasizes form and syntax as well as giving prominence to rhetorical skills (Silva, 1990). Product Writing is "mainly concerned with the knowledge about the structure of language, and writing development is mainly the result of the imitation of input, in the form of texts provided by the teacher" (Badger \& White, 2000). Students are typically told to write an essay emulating a specified pattern. Prodromou (1995), argued that Product Writing devalues "the learners' potential, both linguistic and personal" (p. 21). In short, students are asked to be creative through emulation, but not necessarily to be language-aware or aware of the cultural setting of the text.

In contrast, "[w]riting in process approaches is seen as predominantly to do with linguistic skills, such as planning and drafting, and there is much less emphasis on linguistic knowledge, such as knowledge about grammar and text structure" (Badger \& White, 2000). Students following the Process Approach are trained to write an essay in four main stages: planning, drafting, revising, and editing. Often a back-and-forth approach is taken, whereby "many good writers employ a recursive, non-linear approach. Writing of a draft may be interrupted by more planning, and revision may lead to reformulation, with a great deal of recycling to earlier stages" (Krashen 1984). Students do become more genreaware, and develop a wider set of language sets; however, wider socio-cultural settings are taken for granted.

Shifting the focus to the genre, Hyland (2003) held that genre teaching manages to guide students "toward a conscious understanding of target genres and the way language creates meanings in context" (p. 21). In essence, in order to participate competently in communicative activities, in addition to being linguistically competent, early developers felt that learners need "to become aware of appropriate rhetorical procedures and conventions typically associated with the specialist discourse community they aspire to join" (Miller, 1997). Thus, as Fairclough (1992), pointed out, "a genre implies not only a particular text type, but also particular processes of producing, distributing, and consuming texts" (p. 126), which often involve a narrowing of focus; that is to say, "it is imperative that the specialist learner become aware of restricted aspects of linguistic code in addition to the general competence he or she requires in the language" (Miller, 1997).

\section{Genre-Based Approaches for Teaching Academic Writing}

In 1996 Hyon distinguished three main approaches toward analyzing genres, Rhetorical Genre Studies (RGS), English for Specific Purposes (ESP), and Systemic Functional Linguistics (SFL). Tardy (in Hyland \& Paltridge, 2011) kept this distinction in terms of theoretical grounding and research approaches while pointing out that they agree on general characteristics of the genre as a category of discourse:

a) Genres are primarily a rhetorical category

b) Genres are socially situated

c) Genres are intertextual, not isolated

d) Genres are carried out in multiple and often mixed modes of communication

e) Genres reflect and enforce existing structures of power

Rhetorical Genre Studies. The Genre-Based Approach, oft times termed New Rhetoric in the US, emerged to improve on the outdated models of teaching writing in Australian and North American composition classrooms, which focused on form and end product (Paltridge, 2001; Silva, 1990). In her article Genre as a Social Action, with its pioneering spirit in shaping New Rhetoric Genre Theory within L1 disciplines, Miller (1984), argued that "a rhetorically sound definition of genre must be centered not on the substance or the form of discourse but on the action it is used to accomplish" (p. 151). Similarly, Bazerman (1998), warned that "if we provide our students with only the formal trappings of the genres they need to work in, we offer them nothing more than unreflecting slavery to current practice" (p. 320). 
ESP Genre Analysis. ESP genre analysis is mainly based on "identifying a genre within a discourse community and defining the communicative purpose the genre is designed to achieve" (Bawarshi \& Reiff, 2010). According to these writers, the analysis takes place on both generic structures and textual/linguistic features, such as a register. However, the first consideration is given to how generic structures are characterized by the rhetorical moves they make, and then how these rhetorical moves are carried out through textual and linguistic features. ESP genre analysis thus begins by identifying a genre's generic structure and its context then goes through lexico-grammatical patterns, the text, and textual meaning (Flowerdew, 2002).

Swales' (1990) Move Analysis is a method for analyzing genres within ESP, and "explicitly studies texts in terms of their rhetorical goals and how they work to achieve these goals" (Hyland \& Paltridge, 2011). Swales' research was seminal in shaping genre theory in ESP, by highlighting that a genre refers to a class of communicative events, the members of which share sets of communicative purposes. These purposes are recognized by the expert members of the parent discourse community, and thereby constitute the rationale for the genre. In addition to purpose, exemplars of a genre exhibit various patterns of similarity in terms of structure, style, content, and intended audience (Hyland \& Paltridge, 2011). Scott \& Groom (1999), suggest that genres "are in fact formed out of the dynamics of social interactions involving participants, in particular, social relations" (p. 24). As Paltridge (2007), states, "ESP (and new rhetoric) genre analysts argue that genres are not static but rather change and evolve in response to changes in particular communicative needs" (p. 932).

Systemic Functional Linguistics. SFL "sets out to explain how humans make meaning through language and other semiotic resources, and to understand the relationship between language and the society" (Coffin \& Donohue, 2012). According to Coffin \& Donohue (2012), "text in context is the main unit of analysis in SFL research and the primary constructs for looking at the relationship between text and context are register and genre" (p. 68). From the SFL point of view, proficiency in genres entails awareness of sociological perspectives of a knowledge structure (Muller, 2012). According to Bawarshi \& Reiff (2010), it is believed that the main contribution from SFL on Genre-Based Teaching is the understanding of the genre as social action and its main application is in textual analysis and in language teaching and learning.

The SFL tradition of genre analysis goes back to Halliday's concept of language as a social semiotic; that is, the genre is considered to be a system of meanings. Language is "a form of socialization, playing a role in how individuals become socialized and perform meaningful actions within what (Halliday, 1978) calls contexts of the situation" (Bawarshi \& Reiff, 2010). Genre is defined as "internal linguistic criteria, grouping texts which have similar formal features" (Hyland, 2006). Therefore, "genres have predictable conventions and structures" (Jalilifar, 2014). Although Halliday's functional grammar deals in detail with the structural organization of English clauses, phrases, and sentences, his major contribution to linguistic analysis was to show how simultaneous strands of meanings are expressed in and by clause structures and their contents.

In summary, according to Coffin \& Donohue (2012), SFL is underpinned by the following key tenets:

a) Context and the language choices made by speakers/writers are interrelated.

b) Language is a resource for making meaning.

c) Every utterance/text simultaneously makes three types of meaning, namely Halliday's ideational, interpersonal and textual metafunctions.

d) Language can be viewed and investigated as a total system or as a particular text (or somewhere along that continuum).

Essentially, as defined by Martin \& Rose (2003), the genre is "a staged, goal-oriented social process. Social because we participate in genres with other people; goal-oriented because we use genres to get things done; staged because it usually takes us a few steps to reach our goals" (p. 6). In SFL, it is important to know how "writers and speakers use lexicogrammar to organize and stage whole texts and how this relates to their social purposes" (Coffin et al., 2009). Thus, in focusing on the concepts of genre and register, "much SFL research has focused on describing and accounting for how language works in academic context” (Coffin \& Donohue, 2012).

\section{Genre-Based Pedagogy}

Hyon (1996), reports that "ESP and Australian genre research provides ESL instructors with insights into the linguistic features of written texts as well as useful guidelines for presenting these features in classrooms" (p. 693), while RGS

Ariyanfar, S., \& Mitchell, R. (2020). Teaching writing skills through genre: Applying the genre-based approach in Iran. International Research Journal of Management, IT and Social Sciences, 7(1), 242-257. https://doi.org/10.21744/irjmis.v7n1.843 
focus mainly on "how genres enable their users to carry out situated symbolic actions rhetorically and linguistically" (Bawarshi \& Reiff, 2010). Indeed, within RGS, "understanding contexts (and their performance) is both the starting point of genre analysis and its goal" (Bawarshi \& Reiff, 2010).

Australian Genre Pedagogy is grounded in works such as Halliday (1994); Halliday \& Hasan (1989); Halliday \& Matthiessen (2004); Dossoumou et al. (2018); and Martin (1984, 1989), which highlight the relationships that exist between language, text, and context, as well as Vygotsky's (1980) sociocultural theories of learning. SFL's main contribution has been to help students master different genres at school, much research having been devoted "to developing curricula and teaching strategies for primary and secondary schools" (Horverak, 2016). SFL and the Sydney School are the most productive among the three traditions of Genre-Based Pedagogy, with applicability to both novice native speakers and non-native EFL students. Significant attention to text and its social purpose, context, content domain, and language is given within the accessible teaching/learning cycle (Johns, 2008), applying the view that "language structure is integrally related to social function and context" (Bawarshi \& Reiff, 2010). Subsequently, students should possess the "ability to exercise appropriate linguistic choices in the ways they treat and organize their topics for particular readers, which helps students to give their ideas authority" (Hyland, 2007).

Byrnes (2009), held that Genre-Based Pedagogy allows the class to focus "on the meaning-making or functional quality of language as a semiotic system and of contextualized language use" (p. 2), or, as Derewianka (2012), reminds us, language is a system of meaning, not a set of grammar and words. By applying the Genre-Based Approach, the task of writing becomes more motivating and persuasive. The approach enables learners to see explicitly that, though texts are grammatically and rhetorically patterned, "grammar is integrated into the exploration of texts and contexts rather than taught as a discrete component" (Hyland, 2007). In short, grammar and wording are at the service of the meaning conveyed through written texts.

In practical application, Caplan \& Farling (2017) recommend teachers ground students' development of writing within the cultural and social settings of each type of writing, that is to say, of each genre, be this professional, educational, entertainment, texting, or any other genre as part of the syllabus. It is only then that learners will be able to gain a more direct impetus in their writing by locating the text in its social context. In Jodairi Pineh \& Ariyanfar's (2018) case study (see below), the implementation of the genre-based teaching/learning cycle enabled the researchers to demonstrate in practical terms that the teaching/learning cycle is compatible with Intensive English Program writing curricula and brings numerous benefits to both teachers and learners, thus supporting Caplan \& Farling (2017). Furthermore, by applying genre-based teaching in an Asian educational context, which is perceived to be more teachercentered and examination-oriented (cf. Carless, 2012), the case study explored the feasibility of such teaching in different contexts and responded to Derewianka (2003), for "culturally and sensitive adaptation of genre approaches" (p. 150).

\section{The Genre-Based Approach}

"[G]enres provide a frame that enables learners to take part in and interpret particular communicative events" (Paltridge, 2007). Genre writing classes are usually planned around explicit analyses of samples of the genre so as to increase learners' awareness of overall text organization, recurrent linguistic features and text communicative purposes (Cheng, 2011). Dirgeyasa (2016) saw the main advantage of the Genre-Based Approach with Indonesian students as being particularly helpful for students with low skills and/or motivation through its framework. However, the approach is designed to guide students' development of writing skills in a guided process at all levels, from the most simple, dependent, hesitant steps to being ultimately fully proficient and independent, as it promotes and facilitates student autonomous learning. Whittaker \& Parejo (2018), European study, with its focus mainly on Spanish learners of English, showed that a genre-based approach to writing instruction, through the application of a well-thought-out teaching and learning cycle, has the potential to enhance the improvement of low-achieving pupils by bringing their writing skills more effectively and quickly to the levels of their average and higher-achieving colleagues who have undergone more traditional teaching.

Such recent studies confirm earlier arguments such as Miller (1997): "the learner does not learn language in isolation from specialist contexts but is encouraged to make the relevant connection between the use of language on the one hand and the purpose of communication on the other" (p. 149), and Hammond \& Macken-Horarick (1999): "systematic discussion of language choices in text construction and the development of metalanguage - that is, of functional ways of talking and thinking about language - facilitates critical analysis" (p. 541). 
The Genre-Based teaching-learning Approach is cyclical, as modeled by Martin (1989). The group starts by analyzing and modeling sample argumentative texts in order to explore and demonstrate the social function, organization, and language features of the given genre. Students are expected to read related texts representative of the genre, then students and teacher attempt to "identify the cultural and situational context in which texts in the genre function, what social purposes they serve, how their structural elements reflect their functions, and how their language features carry out their functions" (Bawarshi \& Reiff, 2010). As preparation, students and teachers conduct research, take notes and make observations. Then, the students develop each part of the genre in pairs, followed by group work building their own texts with teacher guidance. After producing different parts of a genre, the students then produce their independent text in the target genre while consulting with the teacher and their peers for editing and evaluating their writing.

\section{Jodairi Pineh and Ariyanfar's Study}

Developing an effective argumentative text in English is a universal challenge for both native and non-native tertiary level students, with one major cause being a lack of linguistic and rhetorical skills. When the student's first language is not English, additional challenges abound, such as inadequate competence in English and differing rhetorical traditions. This was addressed in a Master's thesis entitled "Investigating Roles of Genre Teaching in the Development of EFL Learners' Academic Writing” (Jodairi Pineh \& Ariyanfar, 2018), which looked at the area of developing competent writing skills in English among students through the principles of Gender-based teaching and TBL.

The research questions asked in the study were:

1) "what is the impact of a genre-based pedagogy on the academic writing of a group of Iranian EFL students?"; and

2) "how does this intervention contribute to developing an argument in students' argumentative writing?"

Genre-Based Pedagogy was used to improve the academic writing of fifty students in their second year of a Bachelor of English Language and Translation Studies program. They were notionally CEFR C1 in level. They were divided into two groups, with both groups receiving instruction in a semester-long Academic Writing course. The focus was on the two argumentative genres of exposition and discussion, with "Study Abroad" and "Video Games" respectively chosen as topics. One group consisted of internal students, and the other was external students; their sessions were held off-campus. The course consisted of fourteen 90-minute sessions held twice a week. At the beginning and before any teaching and learning activity, the students were asked to write a "pre-test" text without any prior teaching, beyond what they had already had in their schooling and earlier university coursework. This aimed at providing an initial benchmark to measure any developments in later texts. At the end of the course, the learners were asked to write about the specific topics noted above.

There was no control group, as regular writing skills coursework had been previously run in traditional EFL-ESL product-process approaches. Therefore, in this paper, we compare the results to those gleaned from a random selection of six IELTS Writing Task 1 post-instruction texts produced by participants of a program where the effectiveness of Mobile-Assisted Dynamic Assessment (MADA) of IELTS Writing Task 1 was evaluated (Nasiri \& Moeinpour, 2018). Put simply, they were provided with hints and asked questions through the mobile app in order to have dynamic instruction and guidance. This was a quasi-experimental study, where a group of twenty-three advanced (CEFR C1) users of English took part in a social networking group in Telegram through their mobile phones; their levels were confirmed by the in-class use of the Oxford Practice Test. All had finished university and were at the time in the workforce in fields such as IT, Mechanical Engineering, Electronics, Accounting, Medicine, and Industrial Engineering. The group went through a similar Pre-Test-Instruction-Post-Test process as with Jodairi Pineh \& Ariyanfar's (2018), program. At the end of the program, after the instruction, the participants had improved with a significant increase in their IELTS scores in the post-test. They were also interviewed and expressed a positive perception of MADA. Apart from MADA, the students had previously undergone the standard writing development of their university and IELTS coursework.

Ariyanfar, S., \& Mitchell, R. (2020). Teaching writing skills through genre: Applying the genre-based approach in Iran. International Research Journal of Management, IT and Social Sciences, 7(1), 242-257. 


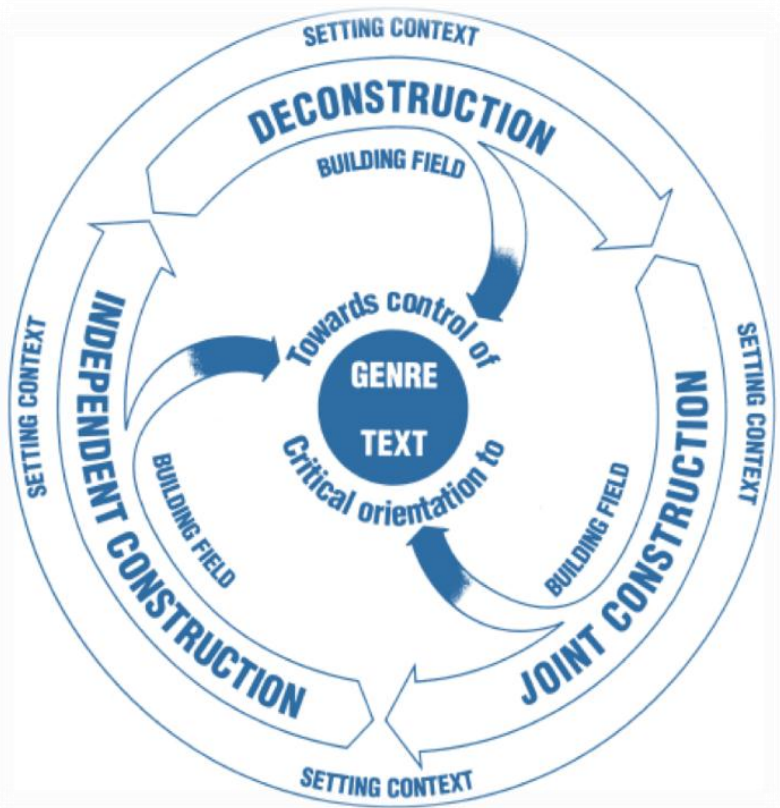

Figure 1. Sydney school genre writing cycles

The approach followed by Jodairi Pineh \& Ariyanfar (2018), adopted a series of teaching and learning cycles aimed at improving the students' awareness of writing skills in their field of study. Other important aspects were the importance of the awareness of cultural and language features; that is to say, awareness of Iranian expectations in academic writing as opposed to those of the Anglo-Saxon world, as well as the teacher's role in helping to engender better argumentation in students' academic writing. The Genre-Based Approach adopted was that of Rothery \& Stenglin (1994), particularly the three main stages of:

a) Deconstruction: explicitly making learners aware of the genre, text organization, types of language, and register through analysis of sample texts.

b) Joint construction: Teacher and students work together to learn how the genre operates, following which teacher and students together compose a new text in the target genre.

c) Independent construction: Students write their own text in the genre.

The course syllabus followed the Genre Writing Cycles developed by the Sydney School (see Figure 1, from Rothery \& Stenglin, 1994), designed to develop student awareness of macro and microstructures of exposition and discussion genres and to enable them to deploy these resources appropriately in their English texts. The course materials were sequenced in such a way that students took both macro and micro language features into account at the same time. During the first stage of the course, the students became aware of culture, the context of the situation, and the language features of a model text. This highlighted the general social purposes of the text and divided the text as a genre model into its component parts. Stage 2 led the students to conscious reflection on the discoveries made in the 1 st stage through group work practice. In Stage 3, the students independently created their own texts. Students were asked to cooperate with each other in brainstorming everything they knew about the subject; this cooperation involving interested students helped to develop ideas to handle difficult issues. At the same time, the teacher contributed positively by helping the students to identify the purpose of the text being written. Finally, students took the important step in becoming independent writers by developing awareness of the sort of language used in different types of texts and understanding how different texts work.

To assess the impact of the approach, 12 pre-course tests, 12 end-of-first-round post-tests, and 12 post-course tests done by 12 participants (randomly selected) were analyzed to assess the presence and use of the interactive and the interactional metadiscourse markers (see Table 1) proposed in Hyland (2006), as well as the retention of rhetorical and lexico-grammatical conventions taught throughout the sessions. Prior to this, informed consent was obtained from all individual participants involved in the study. The coursework was evaluated through semi-structured student and tutor interviews, students' written drafts and revised versions during the course as well as teachers' written feedback. The 
findings indicated that the students deployed a more appropriate and higher percentage of metadiscourse markers in post-course texts than in pre-course writing. It was found that by being aware of interactive and interactional metadiscourse markers, students could argue better, were more able to persuade the reader and produce stronger expository argumentative rhetoric, and through this success became more motivating.

The use of metadiscourse markers was of particular interest. Table 1 gives the percentages of the presence of each in the total number of clauses containing discourse markers in the pre-course texts, and the two post-course exposition and discussion texts.

Table 1

Regular and external learners' average use of metadiscourse markers

\begin{tabular}{lllllll}
\hline \multirow{2}{*}{$\begin{array}{l}\text { Metadiscourse } \\
\text { markers }\end{array}$} & Pretest & \multicolumn{3}{c}{ Exposition } & Discussion \\
\cline { 2 - 6 } & regular & external & regular & external & regular & external \\
\hline Transitions & $51.6 \%$ & $10.16 \%$ & $10.6 \%$ & $17 \%$ & $12.5 \%$ & $17.33 \%$ \\
Evidentials & $0.00 \%$ & $1.16 \%$ & $0.00 \%$ & $2.5 \%$ & $3.5 \%$ & $1.33 \%$ \\
Code glosses & $6.3 \%$ & $6.6 \%$ & $3.3 \%$ & $56 \%$ & $31.6 \%$ & $2.6 \%$ \\
Frame markers & $8.83 \%$ & $8.3 \%$ & $8.83 \%$ & $6.3 \%$ & $3.66 \%$ & $4.5 \%$ \\
Endophorics & $0.3 \%$ & $0.00 \%$ & $0.3 \%$ & $0.00 \%$ & $0.5 \%$ & $1.416 \%$ \\
Hedges & $24.5 \%$ & $38.66 \%$ & $22.6 \%$ & $28.5 \%$ & $26 \%$ & $24.16 \%$ \\
Boosters & $1 \%$ & $5 \%$ & $4.8 \%$ & $4.833 \%$ & $3.1 \%$ & $9.833 \%$ \\
Attitude markers & $1 \%$ & $0.6 \%$ & $1 \%$ & $4.333 \%$ & $1 \%$ & $2.833 \%$ \\
Engagement markers & $21 \%$ & $17.66 \%$ & $22.3 \%$ & $28.83 \%$ & $1.6 \%$ & $18.16 \%$ \\
Self-mentions & $16.16 \%$ & $6.5 \%$ & $1 \%$ & $0.00 \%$ & $0.3 \%$ & $38.33 \%$ \\
\hline
\end{tabular}

Table 2

Regular and external learners' most-used metadiscourse markers

\begin{tabular}{lllll}
\hline Student group & Text type & $1^{\text {st }}$ highest & $2^{\text {nd }}$ highest & $3^{\text {rd }}$ highest \\
\hline Regular Students & Pretest & Transitions: $51,6 \%$ & Hedges: $24.5 \%$ & Engagement: $21 \%$ \\
& Exposition & Hedges: $22.6 \%$ & Engagement: $22.3 \%$ & Transition: $10.6 \%$ \\
& Discussion & Code Glosses: $31.6 \%$ & Hedges: $26 \%$ & Transitions: $12.5 \%$ \\
External Students & Pretest & Hedges: $38.66 \%$ & Engagement: $17.66 \%$ & Transitions: $10.16 \%$ \\
& Exposition & Code Glosses: $56 \%$ & Engagement: $28.83 \%$ & Hedges: $28.5 \%$ \\
& Discussion & Self-mentions: $38.33 \%$ & Engagement: $24.16 \%$ & Transitions: $17.33 \%$ \\
\hline
\end{tabular}

The six post-test texts from Nasiri \& Moeinpour (2018), study were assessed for their use of the same metadiscourse markers. As can be seen from the figures in Tables 3 and 4, these have more in common with the pretests done by the regular group of participants in Tables 1 and 2, with the interesting difference being that frame markers were more frequent than self-mentions, perhaps as a result of the teaching process.

Table 3

Control group's average use of metadiscourse markers

\begin{tabular}{llll}
\hline $\begin{array}{l}\text { Metadiscourse } \\
\text { markers }\end{array}$ & Interactive & Metadiscourse markers & Interactional \\
\hline Transitions & $41.17 \%$ & Hedges & $26 \%$ \\
Evidentials & $0 \%$ & Boosters & $1 \%$ \\
Code glosses & $1.33 \%$ & Attitude mkrs & $1.5 \%$ \\
Frame markers & $15.17 \%$ & Engagement mkrs & $0.33 \%$ \\
Endophorics & $0.5 \%$ & Self-mentions & $4 \%$ \\
\hline
\end{tabular}

Ariyanfar, S., \& Mitchell, R. (2020). Teaching writing skills through genre: Applying the genre-based approach in Iran. International Research Journal of Management, IT and Social Sciences, 7(1), 242-257. https://doi.org/10.21744/irjmis.v7n1.843 
Table 4

Control group's learners' most-used metadiscourse markers

\begin{tabular}{|l|l|l|}
\hline $1{ }^{\text {st }}$ highest & $2^{\text {nd }}$ highest & $3^{\text {rd }}$ highest \\
\hline Transitions: $41,17 \%$ & Hedges:26\% & Frame Markers: $15.17 \%$ \\
\hline
\end{tabular}

The two post-tests produced by students who had undergone the Genre-Based Approach seem more interactional, logical, organized, and easier to comprehend. Quantitative analysis revealed that in the pre-test students used discourse markers mechanically rather than according to their meaning. By contrast, in the two post-tests, it seems that they had started to develop a feeling for literary rhetoric, as can be seen in summary in Table 2 . Their use of the interactive and interactional metadiscourse markers reflected the impression that the students had argued better, could better convince the reader and produced appropriate argumentative texts.

Strategic metadiscourse marker use is of paramount importance in exposition and discussion texts. By using metadiscourse markers, in the two post-tests, students constructed a logical, step-by-step argument. Moreover, they created an interpersonal discourse between the readers and themselves so that their discourse sounded more persuasive. The selected participants in Nasiri \& Moeinpour's (2018), study, however, despite completing a dynamic instruction program, showed much the same uses of discourse markers as the "untrained" production of the participants of Jodairi Pineh \& Ariyanfar's (2018) study. That is to say, their use of discourse markers came across as rather mechanical.

To further assess the efficacy of the trial program, three participants from each group (making sux in all) in Jodairi Pineh \& Ariyanfar's (2018), study were interviewed, with questions mostly dealing with before, during, and after the instruction. The first question explored the students' opinions about writing practices before attending the course, the second question sought to find out the students' ideas on the procedure of the teaching and learning cycles, while the third question dealt with the efficacy of the methodology according to the students' personal experiences. Following this, they were asked to share their feedback on the overall teaching and learning process.

The interviews (for example see Table 5) clearly indicated that the methodology, genre-based teaching and metadiscourse markers awareness development, was indeed a constructive and practical teaching-learning approach. Quantitative findings along with qualitative results showed both the value students placed on feedback received from the teacher and the ways that they responded to it and how they applied their newly learned skills and awareness in subsequent writing. The findings over-all support findings reported by seemingly most researchers that genre-based teaching and learning point the way to better methodologies for teaching academic writing. While the participants in Nasiri and Moeinpour's study likewise had shown improvement and had very positive feedback for the MADA approach, the statistics of discourse marker use suggest that perhaps the program led to an improvement in proficiency with a reinforcement of existing writing strategies.

Table 5

Sample student answers to the interview questions

\begin{tabular}{ll}
\hline Student & Interview answers \\
\hline Mahdi & $\begin{array}{l}\text { It was very helpful for us. With the help of the professor, we corrected our mistakes and all in } \\
\text { all I think it was helpful and informative. }\end{array}$
\end{tabular}

Ali This course was so much useful for me because of lacking the information I need. We had nice times together.

Behzad I found new styles of writing, and I found this class very fruitful. We acquired a good knowledge of English here. This class provided an opportunity. We put our English knowledge into practice.

Mahsa This class opened a new window for us to have more information about academic writing. It was very useful. We had a very interesting class and very fresh. 
Kimia The class was very practical. It was like a workshop. We wrote different argumentative compositions and then emailed them to the instructor. He gave us feedback, mostly on text coherence and text cohesion.

Fatemeh It was very good. We were required to email different writings. The instructor corrected our assignments and provided us with appropriate feedback. Therefore, we could figure out where we have some shortcomings.

\section{Results and Discussions}

Quite a few studies in the world have reported on explicit instruction of metadiscourse markers in experimental studies. These have given broadly similar findings across the range of language skills, including Reading, Listening, and Speaking; namely, that explicit instruction bears fruit. For example, in Iran Tavakoli et al. (2010), reported that explicit instruction of metadiscourse markers plays a fundamental role in participants' achievements in reading comprehension. As most studies make no reference to methodology, it can be presumed that their approach falls within Jalilifar \& Shooshtari's (2011), states that "Most, if not all, students in Iran develop their English language proficiency in traditional, instructional-based settings" (p. 82), that is to say, presumably through product and process.

However, Jalilifar \& Shooshtari (2011), found that explicit instruction is not significantly positive, noting that in their study on explicit instruction of Hedging, that "the proficiency level of students plays a mediatory role ... those students having a higher level of language proficiency may take better advantage of the explicit instruction of hedging" (Jalilifar \& Shooshtari, 2011). This then brings us to their key statement: "Greater proficiency is associated with greater awareness of how language works in context" (Jalilifar \& Shooshtari, 2011). This affects metadiscourse marker use; as many non-native writers lack English language proficiency to varying degrees, they use less interactive and more interactional discourse markers in their writing.

Another study in Iran, Dastjerdi \& Shirzad (2010), both supports as well as giving some evidence against Jalilifar \& Shooshtari's (2011), findings; in their study, with directed instruction to elementary, intermediate, and advanced students, elementary learners improved significantly, while intermediate learners made the greatest improvement. However, their advanced learners showed the least improvement after the instruction. This reflects Simin \& Tavangar (2009), also Iranian, that showed that more highly proficient learners already have a good amount of metadiscourse markers under their belts, and therefore apparently benefit less from explicit instruction.

Results showing that instruction leads to better use of metadiscourse markers link directly to research into the use of metadiscourse markers in personal narrative and argumentative papers, as shown by Alghamdi's (2014) study of 30 academic and 30 non-academic texts produced by sixty students of the Safire Lian Language Institute of Iran. He found that though high-quality essays contain fewer metadiscourse markers, these are used appropriately with their proper meaning/use in the discourse, while poorer writers not only used too many metadiscourse markers (apparently because they seem to think it makes their writing look better) but, more importantly, their use was somewhat mechanical, showing a lack of awareness of the semantics and uses of such markers.

This reflects other research, such as Leńko-Szymańska (2008), which compared the frequencies of metadiscourse markers as used by expert native, novice native, and non-native writers, these latter being advanced learners of English whose first languages were French, Spanish, Swedish, German, Russian, Polish, and Finnish. She found that nonnatives tend to use more metadiscourse markers than expert natives as a matter of form; however, she also found that novice native speaker writers likewise "tend to overuse linking expressions in their texts and that this is a general characteristic of novice writing in English" (p. 15).

Jalilifar (2008), argues that there is a direct and positive relationship between the quality of the compositions and the number of well-functioning metadiscourse markers. He found in his Iranian study that a wide variety of metadiscourse markers are found in good compositions and mechanical repetition of markers in poor compositions, with the exception of a topic relating markers. This largely correlated with age and level of education of the writer. Graduate students tend to use metadiscourse markers better, which leads to more cohesive texts, while students at earlier levels of education tended to have poorer and more frequent use. Overall, Jalilfar's study found that performance depended on how the students had learned English, length of learning, and level of studies and that effective writing skills can take years to develop in the standard EFL product-process focusing teaching models.

Ariyanfar, S., \& Mitchell, R. (2020). Teaching writing skills through genre: Applying the genre-based approach in Iran. International Research Journal of Management, IT and Social Sciences, 7(1), 242-257. https://doi.org/10.21744/irjmis.v7n1.843 
Rahimi (2011), who investigated the frequency and the type of metadiscourse markers used in the argumentative and expository writings of Iranian EFL learners, produced some interesting results. Firstly, the mean of metadiscourse marker use was significantly higher in argumentative essays than in expository essays, probably because in the latter metadiscourse markers are factual and evidential, and there is less need of discourse markers while writing that expresses opinion and discussion needs more metadiscourse markers to signpost steps in opinion and discussion. Such variation was found in Jodairi Pineh \& Ariyanfar (2018), study as well, particularly where interactional metadiscourse markers are concerned. However, in contrast, Rahimi found no evidence that metadiscourse marker use is a significant predictor of writing quality. In his study, as the students had undergone standard product-process approach coursework, one could argue that this failed to create effective improvement. The findings could reflect the tendency of traditional methodology to focus a lot on linkers, metadiscourse markers and so on in a structural sense, without actually giving good instruction in effective semantic usage. This fits in with Leńko-Szymańska (2008), who suggested that less emphasis should be paid to the teaching of linking expressions, and more to "other means of building coherence should be highlighted in the teaching process - constructing a logical argument in which semantic relationships between ideas are self-evident and where the reader requires few overt markers to follow it" (p. 106).

The above studies lead to the supposition that traditional EFL methodologies can lack some effectiveness, seeing that not only can it take years from high school through to the Master's level for students to attain effective writing skills, but that also the actual use of metadiscourse markers is not a good measure of writing quality. How much of this can be put to inefficiencies in the methodology, or a lack of preparedness in the teacher, is difficult to say. Some studies clearly show that a concerted effort to focus on metadiscourse markers can bear fruit; however, others show that what the fruit turns out to be is at times unclear.

Xeketwana's (2018), study into the development of teachers' linguistic awareness of genre in isiXhosa in South African schooling suggests that the Genre-Based Approach is effective, while not being a magic bullet; this mirrors other works that research EFL, including Jodairi Pineh \& Ariyanfar (2018) in Iran, Ueasiriphan \& Tangkiengsirisin (2019) in Thailand, and Whittaker \& Parejo (2018) in Spain as well as in English medium schools (e.g. Lo \& Jeong, 2018, Hong Kong), as well as other languages, such as Arabic as a Foreign Language (e.g. Abdel-Malek, 2019) and language learning in general (e.g. Dolgova \& Tyler, 2019).

An important aspect is that English academic genres have a different orientation from Persian academic genres (Marandi, 2003), and so the socio-cultural settings of genres are a key element of awareness development. Genre-based instruction creates "a conscious understanding of target genres and the ways language creates meanings in context" (Hyland, 2003), which has come to be an important part of teaching and learning of writing in EFL contexts, such as in Indonesia (Douangmala \& Widyantoro, 2018) and Sweden (Kapranov, 2017). Though there are few studies that specifically address the question of metadiscourse markers in genre pedagogy and how the genre approach with its TBL/Communication Approach framework is superior to direct teaching of metadiscourse markers, studies such as Jodairi Pineh \& Ariyanfar (2018), give the general impression that student exploration of metadiscourse marker use in real examples is more effective than being given a list and some direct instruction in their use, which normally reflects structure more than cognition.

The Genre-Based Approach as applied in Jodairi Pineh \& Ariyanfar's (2018) study falls within TBL, as followed by the Sydney Schools, where it has proved to be most effective. Giving the students authentic samples to analyze indepth and highlighting various uses within those samples - including discourse markers - means that students absorb the language and apply it more effectively. Working on the cultural background and setting of the genre reinforces contextual cues and expectations of writing. The teaching is "indirect" in that, while the teacher is aware of what the students need to learn, the teacher guides the students into essentially teaching themselves (e.g., Zheng, 2016). The teacher creates the lessons in such a way so that the students "naturally" learn the lesson, with more exploration and self-teaching, and less direct teaching, applying the principles of Systemic Functional and Cognitive Linguistics.

The findings of Jodairi Pineh \& Ariyanfar's (2018), study as well as other studies referred to all too briefly herein strongly suggest that the application of Genre-based methodology leads to across-the-board improvement in the use of metadiscourse markers as semantic bearers of meaning, along with better writing in general. While the post-test texts from Nasiri \& Moeinpour (2018) showed a more mechanical use of discourse markers, those of Jodairi Pineh \& Ariyanfar (2018), used more interactional than interactive forms after the instruction, showing that the students have absorbed the dialogue nature of writing; that is to say, the writer engages the reader more directly into the text. Qualitatively speaking, in the pre-test, the participants used a number of metadiscourse markers mechanically, while in the two post-tests, their deployment of metadiscourse markers produced logical, coherent persuasive texts. The writing came across as being more logical, organized, and easier to comprehend, suggesting strongly that metadiscourse marker use is of paramount importance in exposition and discussion texts. By using metadiscourse 
markers wisely, students constructed a logical, step-by-step argument. Moreover, they created an interpersonal discourse between the readers and themselves so that their discourse sounded more persuasive.

\section{Conclusion}

\section{Implications for teaching English writing}

Jodairi Pineh \& Ariyanfar's (2018), case study showed that task-based cooperative teaching-learning coursework including contextualization of texts within their social settings allowed the students to explore genres and the language used in and across genres, relating them to their audience and purpose and highlighting the importance of language use in attracting and guiding the reader. The approach proved to be effective and made for more successful and interested writers. However, teachers who have never had the experience of the genre-based approach need to be psychologically and practically prepared. That is to say, to be trained in the methodology (Lo \& Jeong, 2018).

Though the present study was carried out in Iran with a relatively limited number of Iranian students, 12 in Jodairi Pineh \& Ariyanfar (2018), study and six in the control group (Nasiri \& Moeinpour, 2018), and therefore small population and local biases cannot be ruled out, the present paper supports Almacığlu \& Okan's (2018), findings with Turkish EFL students that the writing course syllabus should be designed so as to develop students' overall awareness of the genre or genres they need to learn, thereby enabling them to deploy their awareness appropriately in their English texts. Course materials should be sequenced in such a way that students learn both macro and micro language features at the same time. As a guide to this, Refining Composition Skills: Rhetoric and Grammar for ESL Students by Mary K. Ruetten and Regina Smalley was used in Jodairi Pineh \& Ariyanfar's (2018) case study. The genre-based teachinglearning cycle is best viewed as an upward moving spiral, with exploration, advancement, reviewing, reassessment, more exploration, more advancement, more reviewing, and more reassessment, much as happens in the development of real-life professional writing skills, though the course short-cuts parts of this process. During the first stage of a course, through TBL-based activities, the students are led to an awareness of cultural background, the context of the situation, and the language features of model texts. The TBL approach engages students and enables them to discover genre structure, language, and social context with the teacher's guidance. Where necessary, the teacher can take time out to focus on specific grammar, syntax, or other language points, as well as more detailed socio-cultural contextualization, along with contrastive analysis, contrasting the student's own writing traditions.

Stage 2 represents the practice stage, continuing the TBL approach. The students work in pairs, small groups and as a class with teacher, supervision to consciously reflect on the discoveries made in the 1st stage, and to practice developing the different stages of controlled writing, including research, note-taking, the Introduction, Body, and Conclusion sections, identifying main points, and so on. Attention is continuously drawn back to authentic examples and contextualization to aid in this process. In Stage 3, the production-assessment stage, the students independently create their own texts, with more direct teacher as well as peer involvement in assessing the text, both from the point of view as a document in its own right within its own cultural context, i.e., as an essay within a course being held in English, such as English Translation Studies, as well as from the point of view of the assessment needs of the course, be that a school or university course, an IELTS or TOEFL preparation course, or for professional or personal needs. The teaching of English writing is often far from satisfactory in EFL contexts. Many students continue to have a great deal of difficulty in writing English composition. They find it hard to express their ideas, particularly when it comes to persuasive genres. Better teacher guidance is a way forward, by applying genre-based teaching in different contexts and stages, with a cooperative, task-based syllabus. In this way, students become more familiar with different language functions, more aware of their social context, and more successful and effective in production, as well as reaching proficiency more quickly in comparison to traditional processes. The approach proves to be helpful for curriculum developers in EFL contexts in making for a better selection of teaching materials and strategies. The traditional focus on lexicon and grammatical structures tended to ignore the significance of discourse strategies; the inclusion of genrebased pedagogy widens awareness of the text within its setting and its communicative power in the discourse.

\section{Conflict of interest statement}

The authors declared that they have no competing interests.

Ariyanfar, S., \& Mitchell, R. (2020). Teaching writing skills through genre: Applying the genre-based approach in Iran. International Research Journal of Management, IT and Social Sciences, 7(1), 242-257. 
Statement of authorship

The authors have a responsibility for the conception and design of the study. The authors have approved the final article.

Acknowledgments

We are grateful to two anonymous reviewers for their valuable comments on the earlier version of this paper. 


\section{References}

Abdel-Malek, M. (2019). Writing recounts of habitual events: Investigating a genre-based approach. Foreign Language Annals, 52(2), 373-387. https://doi.org/10.1111/flan.12383

Alghamdi, E. A. (2014). Discourse markers in ESL personal narrative and argumentative papers: a qualitative and quantitative analysis. International Journal of Humanities and Social Science, 4(4), 294-305.

Almacıoğlu, G., \& Okan, Z. (2018). Genre-based approach to writing instruction for students at an English language and literature department. Eurasian Journal of Applied Linguistics, 4(1), 71-100. https://doi.org/10.32601/ejal.460635

Andrews, R. (2005). Models of argumentation in educational discourse. Text-Interdisciplinary Journal for the Study of Discourse, 25(1), 107-127. https://doi.org/10.1515/text.2005.25.1.107

Arsyad, S. (1999). The Indonesian and English argument structure: a cross-cultural rhetoric of argumentative texts. Australian Review of Applied Linguistics, 22(2), 85-102. https://doi.org/10.1075/aral.22.2.06ars

Badger, R., \& White, G. (2000). A process genre approach to teaching writing. ELT journal, 54(2), 153-160. https://doi.org/10.1093/elt/54.2.153

Bawarshi, A. S., \& Reiff, M. J. (2010). Genre: An introduction to history, theory, research, and pedagogy (p. 4). West Lafayette, IN: Parlor Press.

Bazerman, C. (1988). Shaping written knowledge: The genre and activity of the experimental article in science (Vol. 356). Madison: University of Wisconsin Press.

Byrnes, H. (2009). Instructed Foreign Language Acquisition as Meaning-making: A Systemic Functional Approach. Linguistics and Education, 20(1).

Caplan, N. A., \& Farling, M. (2017). A dozen heads are better than one: Collaborative writing in genre-based pedagogy. TESOL Journal, 8(3), 564-581. https://doi.org/10.1002/tesj.287

Caplan, N. A., \& Farling, M. (2017). A dozen heads are better than one: Collaborative writing in genre-based pedagogy. TESOL Journal, 8(3), 564-581.

Carless, D. (2012). From testing to productive student learning: Implementing formative assessment in Confucianheritage settings. Routledge.

Cheng, A. (2011). ESP classroom research: Basic considerations and future research questions. New directions in English for specific purposes research, 44-72.

Choi, Y. H. (1988). Text structure of Korean speakers' argumentative essays in English. World Englishes, 7(2), 129137. https://doi.org/10.1111/j.1467-971X.1988.tb00226.X

Coffin, C., \& Donohue, J. P. (2012). Academic Literacies and systemic functional linguistics: How do they relate?. Journal of English for Academic Purposes, 11(1), 64-75. https://doi.org/10.1016/j.jeap.2011.11.004

Coffin, C., Donohue, J., \& North, S. (2013). Exploring English grammar: From formal to functional. Routledge.

Connor, U., \& Tuija, H. (1988). A contrastive study of persuasive business correspondence: American and Japanese. Global Implications for Business Communications: Theory, Technology and Practice, 57-72.

Connor, U., Gorman, T., \& Vahapassi, A. (1987). The argumentative/persuasive task. The IEA study of written composition, 1, 155-171.

Crowhurst, M. (1988). Research Review: Patterns of Development in Writing Persuasive/Argumentative Discourse.

Dastjerdi, V., \& Shirzad, M. (2010). The impact of explicit instruction of metadiscourse markers on efl learners'writing performance.

Davis, L., \& McKay, S. B. (1996). Structures and strategies: An introduction to academic writing. Macmillan Education AU.

Derewianka, B. (2003). Trends and issues in genre-based approaches. RELC journal, 34(2), 133-154. https://doi.org/10.1177\%2F003368820303400202

Derewianka, B. (2012). Knowledge about language in the Australian curriculum: English.

Dirgeyasa, I. W. (2016). Genre-Based Approach: What and How to Teach and to Learn Writing. English Language Teaching, 9(9), 45-51.

Dolgova, N., \& Tyler, A. (2019). Applications of Usage-Based Approaches to Language Teaching. Second Handbook of English Language Teaching, 939-961. https://doi.org/10.1007/978-3-030-02899-2_49

Dossoumou, A. M., Mehouenou, M. S., \& Koukpossi, A. O. (2018). Appraising the impacts of cohesion and coherence in Benin SS3 EFL learners' writing productions. International Journal of Linguistics, Literature and Culture, 4(5), 41-54. https://doi.org/10.21744/ijllc.v4n5.293

Douangmala, P., \& Widyantoro, A. (2018). The use of genre-based approach instruction to improve students' ability in writing short-essays. International Journal of Science and Research, 7(5), 1141-1145.

Ariyanfar, S., \& Mitchell, R. (2020). Teaching writing skills through genre: Applying the genre-based approach in Iran. International Research Journal of Management, IT and Social Sciences, 7(1), 242-257. https://doi.org/10.21744/irjmis.v7n1.843 
Elachachi, H. (2015). Exploring cultural barriers in EFL Arab learners' writing. Procedia-Social and Behavioral Sciences, 199(3), 129-136.

Fairclough, N. (1992). Discourse and social change (Vol. 10). Cambridge: Polity press.

Flowerdew, J. (2002). Genre in the classroom: A linguistic approach. Genre in the classroom: Multiple perspectives, 91-102.

Halliday, M. A. K. (1978). Language as social semiotic: The social interpretation of language and meaning. Hodder Arnold.

Halliday, M. A. K. (1994). Machine Translation: An Introduction to Functional Grammar. London, Arnold.

Halliday, M. A. K., \& Hasan, R. (1989). Language, context, and text: Aspects of language in a social-semiotic perspective.

Halliday, M. A., \& Matthiessen, C. M. I. M. (2004). An introduction to functional grammar third edition. London: Edward Arnold.

Hammond, J., \& Macken-Horarik, M. (1999). Critical literacy: Challenges and questions for ESL classrooms. Tesol Quarterly, 33(3), 528-544. https://doi.org/10.2307/3587678

Hirose, K. (2003). Comparing L1 and L2 organizational patterns in the argumentative writing of Japanese EFL students. Journal of second language writing, 12(2), 181-209. https://doi.org/10.1016/S1060-3743(03)00015-8

Horowitz, D. (1986). Process, not product: Less than meets the eye. TESOL quarterly, 20(1), 141-144. https://doi.org/10.2307/3586397

Horverak, M. O. (2016, September). An experimental study on the effect of systemic functional linguistics applied through a genre-pedagogy approach to teaching writing. In Yearbook of the Poznan Linguistic Meeting (Vol. 2, No. 1, pp. 67-89). De Gruyter Open. https://doi.org/10.1515/yplm-2016-0004

Hounhanou, A. V. (2018). Evaluating Benin EFL Learners Writing Composition during Final Exam. International Journal of Linguistics, Literature and Culture, 4(2), 9-23.

Hyland, K. (2006). English for academic purposes: An advanced resource book. Routledge.

Hyland, K. (2007). Genre pedagogy: Language, literacy and L2 writing instruction. Journal of second language writing, 16(3), 148-164. https://doi.org/10.1016/j.jslw.2007.07.005

Hyland, K. (2007). Genre pedagogy: Language, literacy and L2 writing instruction. Journal of second language writing, 16(3), 148-164. https://doi.org/10.1016/j.jslw.2007.07.005

Hyland, K., \& Paltridge, B. (Eds.). (2011). Bloomsbury companion to discourse analysis. A\&C Black.

Hyon, S. (1996). Genre in three traditions: Implications for ESL. TESOL quarterly, 30(4), 693-722. https://doi.org/10.2307/3587930

Jalilifar, A. (2008). Discourse Markers in Composition Writings: The Case of Iranian Learners of English as a Foreign Language. English Language Teaching, 1(2), 114-122.

Jalilifar, A. (2014). Workplace discourse. In A. Jalilifar \& S. E. Elhambakhsh (Eds), Directions in Discourse Analysis: Theory and Method (pp. 125-194). Ahvaz, Iran: Chamran University Press

Jalilifar, A. R., \& Shooshtari, Z. G. (2011). Metadiscourse awareness and ESAP comprehension. Journal of College Reading and Learning, 41(2), 53-74. https://doi.org/10.1080/10790195.2011.10850342

Jodairi Pineh, A., \& Ariyanfar, S. (2018). Investigating Roles of Genre Teaching in the Development of EFL Learners' Academic Writing, MA thesis, Zanjan University.

Johns, A. M. (1993). Written argumentation for real audiences: Suggestions for teacher research and classroom practice. TESOL quarterly, 27(1), 75-90. https://doi.org/10.2307/3586952

Johns, A. M. (2008). Genre awareness for the novice academic student: An ongoing quest. Language Teaching, 41(2), 237-252. https://doi.org/10.1017/S0261444807004892

Kapranov, O. (2017). The use of metonymy and metaphor in descriptive essays by intermediate and advanced EFL students. Linguistics Beyond and Within (LingBaW), 3(3), 87-101.

Knudson, R. E. (1994). An analysis of persuasive discourse: Learning how to take a stand. Discourse Processes, 18(2), 211-230. https://doi.org/10.1080/01638539409544892

Krashen, S. D. (1984). Writing, research, theory, and applications. Pergamon.

Leńko-Szymańska, A. (2008). Non-native or non-expert? The use of connectors in native and foreign language learners' texts. Acquisition et interaction en langue étrangère, (27), 91-108.

Lo, Y. Y., \& Jeong, H. (2018). Impact of genre-based pedagogy on students' academic literacy development in Content and Language Integrated Learning (CLIL). Linguistics and Education, 47, 36-46. https://doi.org/10.1016/j.linged.2018.08.001

Marandi, S. (2003). Metadiscourse in Persian/English master's theses: A contrastive study. 
Martin, J. R. (1984). Language, register and genre. Children writing: reader, 1, 984.

Martin, J. R. (1989). Factual writing: Exploring and challenging social reality. Oxford University Press, USA.

Martin, J. R. (1989). Factual writing: Exploring and challenging social reality. Oxford University Press, USA.

Martin, J. R., \& Rose, D. (2003). Working with discourse: Meaning beyond the clause. Bloomsbury Publishing.

Miller, C. R. (1984). Genre as social action. Quarterly journal of speech, 70(2), 151-167. https://doi.org/10.1080/00335638409383686

Miller, T. (1997). Functional Approaches to Written Text: Classroom Applications.

Mohan, B. A., \& Lo, W. A. Y. (1985). Academic writing and Chinese students: Transfer and developmental factors. TESOL quarterly, 19(3), 515-534. https://doi.org/10.2307/3586276

Muller, J. (2012). Reclaiming knowledge: Social theory, curriculum and education policy. Routledge.

Nasiri, M., \& Moeinpour, L. (2018). Dynamic assessment of IELTS writing task one through mobile learning in the context of Iranian EFL learners. MA thesis, Zanjan University.

Paltridge, B. (2001). Genre and the language learning classroom. University of Michigan Press.

Paltridge, B. (2007). Approaches to genre in ELT. In International handbook of English language teaching (pp. 931943). Springer, Boston, MA. https://doi.org/10.1007/978-0-387-46301-8_62

Pennington, M. C. (1995). The teacher change cycle. Tesol Quarterly, 29(4), 705-731. https://doi.org/10.2307/3588171

Prodromou, L. (1995). The backwash effect: from testing to teaching. https://doi.org/10.1093/elt/49.1.13

Rahimi, M. (2011). Discourse markers in argumentative and expository writing of Iranian EFL learners. World Journal of English Language, 1(2), 68. http://dx.doi.org/10.5430/wjel.v1n2p68

Rothery, J., \& Stenglin, M. (1994). Writing a book review: A unit of work for junior secondary English (Write it Right Resources for Literacy and Learning). Sydney: Metropolitan East Disadvantaged Schools Program.

Scott, M., \& Groom, N. (1999). Genre-based pedagogy: Problems and possibilities. Issues in EAP research and writing instruction. Reading: Centre for Applied Language Studies, University of Reading.

Silva, T. (1990). Second language composition instruction: Developments, issues, and directions in ESL. Second language writing: Research insights for the classroom, 11-23.

Simin, S., \& Tavangar, M. (2009). Metadiscourse knowledge and use in Iranian EFL writing. The Asian EFL Journal Quarterly March 2009 Volume 11, Issue, 230.

Stuart-Smith, V. (1998). Constructing an argument in psychology: Rhetorical structure theory and the analysis of student writing. Researching academic literacies, 31-146.

Swales, J. (1990). Genre analysis: English in academic and research settings. Cambridge University Press.

Tavakoli, M., Dabaghi, A., \& Khorvash, Z. (2010). The Effect of Metadiscourse Awareness on L2 Reading Comprehension: A Case of Iranian EFL Learners. English Language Teaching, 3(1), 92-102.

Thompson, G. (2001). Interaction in academic writing: Learning to argue with the reader. Applied linguistics, 22(1), 58-78. https://doi.org/10.1093/applin/22.1.58

Ueasiriphan, T., \& Tangkiengsirisin, S. (2019). The Effects of Genre-Based Teaching on Enhancement of Thai Engineers' Technical Writing Ability. International Journal of Instruction, 12(2), 723-738.

Vygotsky, L. S. (1980). Mind in society: The development of higher psychological processes. Harvard university press.

Whittaker, R., \& Parejo, I. G. (2018). Teacher Learning for European Literacy Education (TeL4ELE): genre-based pedagogy in five European countries. European Journal of Applied Linguistics, 6(1), 31-57. https://doi.org/10.1515/eujal-2017-0021

Xeketwana, S. (2018). A theoretical approach to teaching academic literacy through the use of genres: A knowledge about language for preservice teachers. South African Journal of African Languages, 38(3), 349-354. https://doi.org/10.1080/02572117.2018.1518050

Zheng, L. (2016). The effectiveness of self-regulated learning scaffolds on academic performance in computer-based learning environments: A meta-analysis. Asia Pacific Education Review, 17(2), 187-202. https://doi.org/10.1007/s12564-016-9426-9

Ariyanfar, S., \& Mitchell, R. (2020). Teaching writing skills through genre: Applying the genre-based approach in Iran. International Research Journal of Management, IT and Social Sciences, 7(1), 242-257. 